\title{
$\begin{array}{ll}\text { Research Square } & \begin{array}{l}\text { Preprints are preliminary reports that have not undergone peer review. } \\ \text { They should not be considered conclusive, used to inform clinical practice, } \\ \text { or referenced by the media as validated information. }\end{array}\end{array}$
}

\section{Criopreservation of Pacu sperm (Piaractus mesopotamicus, Holmberg, 1887)}

\section{Adriano Rayol da Silva}

FURG: Universidade Federal do Rio Grande

\section{CARINE DAHL CORICNI}

UFPEL: Universidade Federal de Pelotas

\section{Fernanda Pereira Alves}

FURG: Universidade Federal do Rio Grande

\section{Sara Lorandi Soares}

UFPEL: Universidade Federal de Pelotas

\section{Andréia Nobre Anciutti}

UFPEL: Universidade Federal de Pelotas

\section{Jorge Squeff Filho}

UFPEL: Universidade Federal de Pelotas

\section{Rodrigo Desessards Jardim}

FURG: Universidade Federal do Rio Grande

\section{Juan R. Esquivel-Muelbert}

Macquarie University College of Science and Technology: Macquarie University Faculty of Science and Engineering

\section{Juan Ramon Esquivel Garcia}

UFSC: Universidade Federal de Santa Catarina

Antonio Sergio Varela Junior ( $\sim$ antoniovarela@furg.br)

Universidade Federal do Rio Grande https://orcid.org/0000-0003-4901-5118

\section{Short Report}

Keywords: CASA, cryopreservation, DMSO, flow cytometry, glycerol, methanol

Posted Date: February 24th, 2022

DOI: https://doi.org/10.21203/rs.3.rs-1379415/v1

License: () This work is licensed under a Creative Commons Attribution 4.0 International License. Read Full License 


\section{Abstract}

Due to the absence of effective cryopreservation methods for oocytes in fish, there has been a significant focus on protocols for the cryopreservation of male gametes to maintain genetic diversity in captive populations. This study evaluated the efficiency of various penetrating cryoprotectants that may lead to better conservation of Piaractus mesopotamicus sperm characteristics. The sperm samples were collected from 14 wild males by applying light abdominal compressions and diluted in Beltsville Thawing Solution (BTS), along with the following cryoprotectants at concentrations of $5 \%, 7.5 \%, 10 \%, 12.5 \%$, and $15 \%$ : dimethyl sulfoxide (DMSO), glycerol, and methanol. Kinetics of spermatozoa and cellular integrity was estimated after thawing. Sperm motility was observed to be nil for all samples for glycerol concentrations higher than $7.5 \%$. Usage of DMSO showed less than $11 \%$ motility and less than $19 \mathrm{~s}$ duration of motility at all concentrations. Sperm motility was greater than $20 \%$ with a $>30$ s period of motility when using methanol. We recommend, based on our observations, that using $7.5 \%$ methanol added to BTS diluent exhibits the best sperm kinetics and cell functionality $(P<.05)$ for sperm cryopreservation of Pacu $(P$. mesopotamicus).

\section{Introduction}

An effective cryopreservation protocol must take into account the varying biochemical characteristics of the sperm from different fish species, varying handling and treatment requirements at the time of freezing, as well as between different aliquots from the same animal. So, for a sperm cryopreservation protocol to be well-established, standardization of protocols based on the quality of the samples is a priority for researchers (Cabrita et al., 2010).

The Piaractus mesopotamicus, commonly known as Pacu, is a rheophilic fish capable of migrating upstream (potamodromous) for spawning (Urbinati et al., 2005). It is widely distributed in South America, reported from the Paraná-Paraguay river basin to the Prata basin (Godoy, 1975). The Pacu is an important part of the river ecology due to the role it plays in seed dispersal in the riparian forests, helping in its conservation and restoration (Muniz al., 2014), which, along with its attractive zootechnical characteristics, have prompted the adoption of numerous techniques to safeguard to the reproductive biology and sperm quality of the species (Paulino et al., 2018; Maria et al., 2015).

In this context, this study aimed to evaluate the efficacy of the penetrating cryoprotectants DMSO, glycerol, and methanol, on parameters of cryopreserved Pacu sperm kinetics and the conservation of intracellular integrity.

\section{Materials And Methods}

Sperm collection and freezing were performed during the spawning season of the fish in November at the Panamá LTDA fish-farms in Paulo Lopes, Santa Catarina, Brazil (2757'37.8"S and 4845'29"W).

Fourteen wild $P$. mesopotamicus males $(\mathrm{n}=14)$ were acclimatized on the property and hormonally stimulated with crude carp hypophysis extract $(0.5 \mathrm{mg} / \mathrm{kg})$ and transferred to $1000-\mathrm{L}$ polyethylene tanks till the time of sampling. Fish were wrapped in damp cotton towels to reduce stress, and slight abdominal compressions were applied following hormonal induction (in cranio-caudal sense), avoiding premature activation or contamination of the samples by feces, urine, or blood. Samples were stored at $10^{\circ} \mathrm{C}$ in $15 \mathrm{~mL}$ tubes (one per fish).

The samples were assessed by trained technicians using a phase-contrast microscope (Olympus BX41) for sperm motility with and without activation (Varela et al., 2012). A $1 \mu \mathrm{L}: 4 \mu \mathrm{L}$ dilution with BTS and water was used to assess the motility of non-activated and activated sperm, respectively, on a slide with a coverslip (Kuradomi et al., 2016). Samples in BTS showing motility from previous activations or those with less than $80 \%$ motility in water were discarded. The samples should have characteristics such as pH between 8.0 and 8.2 , Osmolality of $208 \mathrm{mOsmol} / \mathrm{kg}$, 
with an average concentration of $3.5 \times 10^{10}$ sperm/ mL, parameters visualized with reproductive phase of this species by Kuradomi et al., 2016.

Freezing of spermatozoa involved 15 treatments per fish sampled (DMSO, glycerol, and methanol at concentrations of $5 \%, 7.5 \%, 10 \%, 12.5 \%$, and $15 \%$ ) in duplicate to avoid losses during thawing, totaling 420 vials. All treatments were diluted in BTS with pH adjusted at 7.2 and osmolarity of 320 mOsm (Varela Junior et al., 2012).

Collected sperm were aliquoted in $1.5 \mathrm{~mL}$ microcentrifuge tubes containing the freezing solutions, diluted to a final concentration of $2 \times 10^{6}$ sperm/ $\mathrm{mL}$ in $250 \mu \mathrm{L}$ plastic vials, sealed with polyvinyl alcohol, and placed in metal racks for cooling at $5^{\circ} \mathrm{C}$ for $20 \mathrm{~min}$. Racks were then transferred to a nitrogen vapor dry shipper (Taylor-Wharton, model CP300) for $12 \mathrm{~h}$, followed by transfer to a liquid nitrogen cylinder (MVE, model CP-34) for long-term storage, i.e., until the time of thawing and analysis of the samples.

Samples were quickly thawed in a $37^{\circ} \mathrm{C}$ water bath for $8 \mathrm{~s}$. Sperm motility was evaluated using Computer Assisted sperm analysis using Sperm Vision ${ }^{\circledR}$ software (Minitube). Activation was achieved using a 1:5 dilution of samples with distilled water and observed on a slide with a coverslip. Around 20 fields, containing a minimum of 50 motile cells each, totaling 1000 cells for the analysis were considered for kinetics, with fields being assessed between $10 \mathrm{~s}$ and $15 \mathrm{~s}$ after activation (Varela et., 2012).

Analyses for intracellular integrity were performed by flow cytometry and assessed for mitochondrial functionality, cellular membrane integrity, DNA fragmentation index (DFI), lipid peroxidation (LPO) and reactive oxygen species (ROS) on an Attune Acoustic Focusing Flow Cytometer (Life Technologies) with blue (Argon $488 \mathrm{~nm}$ ) and violet (UV $405 \mathrm{~nm}$ ) lasers. Data were analyzed using the Attune ${ }^{\circledR}$ Cytometer software version 2.1.0 (Life Technologies). Around 20,000 events per sample were analyzed at a flow rate of $100 \mu \mathrm{L} / \mathrm{min}$.

Plasma membrane integrity was evaluated using double fluorescent staining with SYBR14/Propidium lodide (PI) (Minitube, Tiefenbach, Germany) as described previously Alves et al., (2016)).

Plasma membrane was expressed as a percentage using the calculation: [(Number of sperm with low fluidity)/ (Number of sperm with low fluidity + Number of sperm with high fluidity)] $\times 100]$. Cells were classified by high fluorescence (high fluidity) and low fluorescence (low fluidity) (Alves et al., 2016).

Rhodamine being a mitochondrial, a mixture of $20 \mu \mathrm{M} \mathrm{PI}$ and $7.5 \mu \mathrm{M}$ rhodamine 123 was used to quantify populations based on mitochondrial functionality after incubated for $10 \mathrm{~min}$ (Alves et al., 2016).

DNA fragmentation index (DFI) was quantified using the sperm chromatin structure assay (SCSA®) (Alves et al., 2016). DFI was expressed as a percentage using the formula: [(Number of spermatozoa with fragmented DNA)/(Number of spermatozoa with intact DNA) + (Number of spermatozoa with fragmented DNA)] $\times 100$.

Lipid peroxidation (LPO) was measured immediately after the thawing of samples by incubating with $1 \mu$ M of BODIPY ${ }^{\circledR}$ $581 / 591 \mathrm{C} 11$ in $10 \mu \mathrm{L}$ and incubated for $5 \mathrm{~min}$ (bottom) and $2 \mathrm{~h}$. LPO rate was calculated, after accounting for background fluorescence, by: [(Median green fluorescence intensity)/(Median green fluorescence intensity) + (Median red fluorescence intensity) $] \times 100$.

Reactive oxygen species (ROS), the median intensity of green fluorescence (emitted upon oxidation) was used to quantify ROS, after gating on live sperm (PI-), excluding cells with a ruptured membrane (permeable to PI) (Alves et al., 2016). 
Quantifications were tested for normality using the Shapiro-Wilk test, followed by an analysis of variance (ANOVA) and a post hoc Tukey test. All analyses were performed using the Statistix 2010 software.

\section{Results}

Fresh sperm upon evaluation showed a mean ( \pm standard error) of total motility (TM) of $95.3 \pm 3.7 \%$ and a motility period (MP) of $81.7 \pm 12.6 \mathrm{~s}$. Sperm motility during the cryopreservation process has a significant loss. Of the treatments used in this work, the use of the diluent with methanol at a concentration of $7.5 \%$ showed a higher percentage of total motility (30.1 $\pm 1.4 \%$ ) (Fig. 1a) and (progressive motility $22.1 \pm 1.3 \%$ ) (Fig. 1b) $(P<0.05)$, when compared to other post-thaw treatments.

Considering the sperm cell as a machine in which all structures are important for it to perform its function, Methanol in the concentration of 5 and $7.5 \%$ showed better results in the motility period (Fig. 1c) and mitochondrial functionality variables (Table 1). The methanol at $10 \%$ and $15 \%$ concentrations showed the highest DNA fragmentation index $(P>$ 0.05).

Table 1

Evaluation of the integrity of the cell structures of thawed pacu sperm by flow cytometry. Membrane integrity (MI), membrane fluidity (MF), mitochondrial functionality (MIF), DNA fragmentation index (DFI), lipid peroxidation (LPO) and reactive oxygen species (ROS). The data are expressed as mean and standard error of the mean. '

\begin{tabular}{|c|c|c|c|c|c|c|}
\hline Treatments(\%) & MI (\%) & $M F(\%)$ & MIF(\%) & DFI(\%) & LPO(\%) & ROS(\%) \\
\hline DMSO 5 & $45.3 \pm 7.0^{d}$ & $67.4 \pm 6.6^{a}$ & $68.1 \pm 4.8^{a b c}$ & $0.05 \pm 0.006^{c}$ & $46.5 \pm 4.5^{\mathrm{a}}$ & $2522.8 \pm 318.72^{c}$ \\
\hline DMSO 7.5 & $56.8 \pm 3.8^{\mathrm{abcd}}$ & $48.9 \pm 7.1^{a}$ & $69.0 \pm 6.0^{a b c}$ & $0.05 \pm 0.002^{c}$ & $45.9 \pm 5.3^{a}$ & $2116.1 \pm 238.7^{c}$ \\
\hline DMSO 10 & $59.9 \pm 3.6^{\mathrm{abcd}}$ & $42.0 \pm 7.8^{\mathrm{a}}$ & $68.1 \pm 6.7^{\mathrm{abc}}$ & $0.04 \pm 0.004^{c}$ & $46.9 \pm 5.1^{\mathrm{a}}$ & $4582.0 \pm 1262.3^{b}$ \\
\hline DMSO 12.5 & $69.0 \pm 4.1^{\mathrm{ab}}$ & $53.5 \pm 8.6^{a}$ & $72.6 \pm 7.6^{a b}$ & $0.06 \pm 0.007^{c}$ & $50.0 \pm 4.9^{a}$ & $2323.2 \pm 242.4^{c}$ \\
\hline DMSO 15 & $70.8 \pm 4.4^{a}$ & $44.6 \pm 9.3^{a}$ & $68.4 \pm 7.6^{a b c}$ & $0.05 \pm 0.005^{c}$ & $46.2 \pm 4.7^{a}$ & $3319.9 \pm 620.7^{c}$ \\
\hline GLY 5 & $45.5 \pm 7.3^{d}$ & $59.3 \pm 9.5^{a}$ & $57.8 \pm 7.4^{\text {bcde }}$ & $0.07 \pm 0.01^{b c}$ & $45.4 \pm 4.9^{a}$ & $2404.2 \pm 211.0^{c}$ \\
\hline GLY 7.5 & $55.4 \pm 7.0^{\mathrm{abcd}}$ & $57.9 \pm 9.5^{\mathrm{a}}$ & $47.5 \pm 7.8^{\mathrm{de}}$ & $0.06 \pm 0.007^{b c}$ & $40.9 \pm 4.7^{a}$ & $2473.7 \pm 220.9^{c}$ \\
\hline GLY 10 & $63.4 \pm 6.9^{a b c}$ & $49.3 \pm 9.5^{a}$ & $48.9 \pm 8.0^{\text {cde }}$ & $0.06 \pm 0.006^{c}$ & $50.7 \pm 5.9^{a}$ & $4707.2 \pm 253.1^{b}$ \\
\hline GLY 12.5 & $60.1 \pm 6.6^{\mathrm{abcd}}$ & $41.5 \pm 9.2^{\mathrm{a}}$ & $45.8 \pm 9.1^{\mathrm{de}}$ & $0.04 \pm 0.004^{\mathrm{c}}$ & $47.8 \pm 5.7^{\mathrm{a}}$ & $1984.8 \pm 168.7^{c}$ \\
\hline GLY 15 & $59.1 \pm 6.8^{\mathrm{abcd}}$ & $52.8 \pm 9.2^{\mathrm{a}}$ & $44.7 \pm 7.5^{\mathrm{de}}$ & $0.05 \pm 0.007^{c}$ & $51.6 \pm 3.5^{\mathrm{a}}$ & $1638.9 \pm 146.3^{c}$ \\
\hline METH 5 & $58.6 \pm 6.6^{\mathrm{abcd}}$ & $49.1 \pm 10.4^{a}$ & $61.7 \pm 9.1^{\text {abcde }}$ & $0.07 \pm 0.01^{b c}$ & $42.2 \pm 4.8^{a}$ & $2653.5 \pm 311.11^{c}$ \\
\hline METH 7.5 & $54.7 \pm 6.3^{\mathrm{abcd}}$ & $48.2 \pm 9.1^{a}$ & $80.6 \pm 5.8^{a}$ & $0.06 \pm 0.005^{b c}$ & $39.9 \pm 5.4^{\mathrm{a}}$ & $4837.8 \pm 2472.3^{a b}$ \\
\hline METH 10 & $52.4 \pm 5.3^{\mathrm{bcd}}$ & $50.2 \pm 9.8^{a}$ & $60.7 \pm 8.0^{\text {abcde }}$ & $0.1 \pm 0.03^{a}$ & $53.0 \pm 3.5^{\mathrm{a}}$ & $2389.9 \pm 1219.7^{c}$ \\
\hline METH 12.5 & $48.1 \pm 7.1^{\mathrm{cd}}$ & $58.8 \pm 10.3^{a}$ & $71.1 \pm 6.0^{\mathrm{ab}}$ & $0.06 \pm 0.008^{b c}$ & $61.7 \pm 5.7^{\mathrm{a}}$ & $8604.9 \pm 3980.8^{a}$ \\
\hline METH 15 & $49.6 \pm 5.4^{\mathrm{cd}}$ & $55.2 \pm 12.8^{a}$ & $67.1 \pm 8.6^{\mathrm{abcd}}$ & $0.1 \pm 0.04^{a}$ & $48.0 \pm 4.6^{a}$ & $1090.8 \pm 216.5^{c}$ \\
\hline
\end{tabular}


However, methanol treatment also presented the highest ROS levels as compared to other cryoprotectants (Table 1). DMSO and glycerol treatments showed low levels of ROS, with no significant difference between them $(P>0.05)$.

\section{Discussion}

The use of cryopreservation of sperm cells is associated with cellular and molecular damage, affecting the functionality of mitochondria and cell membrane, in fish there is still a large field of research. In this work, methanol was considered a cryoprotectant that better preserved the structures and functionalities of the Pacu sperm cell. The progressive or total sperm motility in the treatment with methanol showed higher rates in relation to all treatments up to the concentration of $12.5 \%$.

Methanol is a cryoprotectant that does not change the volume of sperm when entering or leaving the cell (Hagedorn et al., 2009). With the use of methanol, the lack of osmotically induced cell volume excursion makes it an ideal cryoprotectant for gamete cryopreservation. For these observations on all of the Methanol 5 and $7.5 \%$ concentrations are adequate to preserve the quality after thawing of the semen Pacu.

MP of sperm of freshwater fish range between $30 \mathrm{~s}$ and $60 \mathrm{~s}$, placing the results obtained in this study with $7.5 \%$ methanol (67.6 s $\pm 7.4 \mathrm{~s}$ ) within the acceptable range for the reproduction of Pacu (Billard 1986). Higher kinetic activity is directly proportional to greater success of oocyte fertilization in an aquatic environment, and is thus, of great importance for the perpetuation of the species, especially in captive breeding programs and pisciculture using artificial insemination (Cabrita et al., 2010).

Among the most commonly used cryoprotectants used for cryopreservation of sperm in fish is DMSO, owing to its high solubility and intracellular permeability, although it does not always yield the best results in terms of kinetics and sperm quality (Viveiros et al.,2014; Cabrita et al., 2010). Studies with tambaqui sperm (Colossoma macropomum) by Varela Junior et al., (2012) yielded acceptable sperm quality after freezing and thawing with 10\% DMSO. In the present study, $10 \%$ DMSO yielded similar results to those of Varela Junior et al., (2012), although methanol 7.5\% performed better. Hargedorn et al., (2009) visualized that DMSO increases cell volume during exposure, altering cell structure, which may be indicative due to the decrease in motility observed in this study.

Both kinetics and flow cytometry results demonstrated $7.5 \%$ methanol to be successful in preserving most of the evaluated parameters. Being highly soluble in aqueous solvents, coupled with its high permeability and low toxicity profile, methanol is a preferred cryoprotectant for many fish species, apart from the endangered species Brycon orbignyanus (Harvey and Carolsfeld, 1993).

The effect of glycerol on membrane fluidity demonstrated that this parameter did not lose its selective function during freezing, staying intact, and fluid. Due to the structural arrangement of the membrane, a gel-like structure forms as a result of interactions with phospholipids, protein, and glycoprotein bonds, thus reducing the influx of water and lowering the intracellular osmotic pressure (Parks \& Graham, 1992).

MIF was prominent in the methanol treatments, while being similar in all other treatments. Being responsible for generating sperm motility through ATP biosynthesis via the electron transport system and oxidative phosphorylation during cellular respiration (Amaral et al., 2016), high mitochondrial activity may also lead to higher ROS levels. This may explain the highest ROS levels for methanol treatments, given that they also showed high MIF scores.

Methanol also recorded high LPO concentrations, while treatment with other agents showed similar results. Post-thaw analyses of Suruvi fish sperm (Pereira et al., 2018) cryopreserved with methanol and DMSO were similar to results obtained in this study. Additionally, higher ROS levels than those in this study were also recorded in $A$. minuano

Page 5/9 
spermatozoa (Fernandes et al., 2019). Higher ROS levels indicate increased oxidative stress that can hamper membrane fluidity and LPO, lower MIF, and cause DNA oxidation, all of which can compromise sperm quality and viability (Silva et al., 2016). It is, therefore, essential to keep ROS levels low during and after sperm cryopreservation (Shaliutina et al., 2013).

Less than 5\% DFI was observed in this study, indicating that genetic integrity was maintained even with high levels of oxidative stress. This result is in accordance with previous reports (Patryka et al., 2010) of spermatozoan chromatin being more condensed than earlier developmental stages (spermatogonia, spermatocytes, and spermatids) and the presence of the nuclear envelope offers more protection to the paternal genetic from external damage (Cabrita et al., 2010).

Among the cryoprotectants evaluated in this study, methanol has the lowest molecular weight that may result in its high permeability, which helps avoid intracellular damage and cryoinjury to a greater extent than other agents. This, along with its higher MIF scores, also aids in obtaining higher sperm kinetic values than other cryoprotectants, although higher sensitivity of sperm to greater concentrations of methanol was demonstrated in this study. We recommend avoiding greater than $7.5 \%$ concentrations for cryopreservation of freshwater fish sperm.

\section{Conclusion}

This study informs the safe use of 7.5\% methanol added to BTS diluent for the cryopreservation of Pacu spermatozoa, ensuring motile and viable spermatozoa post-thawing, demonstrating that methanol is an effective cryoprotectant agent for fish germplasm.

\section{Declarations}

\section{Acknowledgements}

We would like to thank the Coordination for the Personal Improvement of Higher Education (CAPES, Brasília, DF, Brazil) for the post-graduate scholarships awarded to Adriano Rayol da Silva, Fernanda Alves Pereira, Sara Lorandi Soares, Andréia Nobre Anciutti and Jorge Squeff Filho; research grants from Antonio Sergio Varela Junior (310327/2018-0) and Carine Dahl Corcini (310203/2018-0). We also thank the Pisciculture Panamá (Paulo Lopes, SC, Brazil) and the Comparative Animal Reproduction group (Federal University of Rio Grande, Rio Grande, RS, Brazil) for the assistance during this work.

\section{Conflicts of Interest}

The authors declare that they do not have any commercial or associative interest that represents a conflict of interest in connection with the work submitted.

\section{Funding information}

Coordenação de Aperfeiçoamento de Pessoal de Nível Superior (CAPES); Fundação de Amparo à Pesquisa do Estado do Rio Grande do Sul (FAPERGS)

\section{Author contributions statement}

C.D.C, A.S.V.J, A.R.S, F.P.A., S.L.S, A.N.A., R.D.J., J.R.E.M and J.R.G conceived and planned the experiments. J.S.F., A.R.S, F.P.A., S.L.S, A.N.A., C.D.C and A.S.V.J. carried out the experiments. C.D.C, A.S.V.J, R.D.J., J.R.E.M and J.R.G contributed 
to the interpretation of the results. All authors provided critical feedback and helped shape the research, analysis, and manuscript.

All experiments and animal handling performed in this study were in compliance with the Ethics Committee on Animal Use (CEUA) of the Federal University of Rio Grande, RS approved ordinance 0423/2016.

Code or data availability - not applicable

Consent to participate - not applicable

Consent for publication - not applicable

\section{References}

Ahn, J.Y., Park, J.Y. \& Lim, H.K. (2018). Effects of different diluents, cryoprotective agents, and freezing rates on sperm cryopreservation in Epinephelus akaara. Cryobiology, 83, 60-64. https://doi. org/10.1016/j.cryobiol.2018.06.003.

Alves, J.P., Corcini, C.D., Silva, E.F.E., Caldas, J.S., Cardoso, T.F., Piedras, S.R.N., Jardim, R.D. \& Varela Junior, A.S. (2016). The role of amides in seminal cryopreservation of wild silverside, Odontesthes bonariensis. Cryobiology 73, $383-387$. https://doi.org/10.1016/j.cryobiol.2016.09.001.

Amaral, S., Tavares, R.S., Baptista, M., Sousa, M.I., Silva, A., Escada-Rebelo, S. \& Ramalho-Santos, J. (2016). Mitochondrial Functionality and Chemical Compound Action on Sperm Function. Curr. Med. Chem., 23(31), 3575-3606. https://doi.org/ 10.2174/0929867323666160425113518.

Billard R., (1986).Spermatogenesis and spermatology of some teleost fish species. Reprod. Nutr. Develop., 26, 877-920. https://dx.doi.org/10.1051/rnd:19860601.

Cabrita, E., Sarasquete, C., Martínez-Páramo, S., Robles, V., Beirão, J., Pérez-Cerezales, S. \& Herráez, M.P. (2010). Cryopreservation of fish sperm: applications and perspectives. J. Appl. Ichthyol, 26, 623635. https://doi.org/10.1111/j.1439-0426.2010.01556.x.

Fernandes, M.D.O., Garcez, D.K., Acosta, I.B., Gheller, S.M.M., Corcini, C.D., Robe, L.J. \& Varela Junior, A.S. (2019). Cryopreservation of sperm in annual fish Austrolebias minuano (Cyprinodontiformes; Rivulidae). Aquac. Res., 51, 147-154. https://doi.org/10.1111/are.14356.

Godoy, M.P. 1975. Peixes do Brasil: subordem Characoidei. Bacia do rio Mogi-Guassu. Piracicaba: Franciscana, pp. 1-4. Hagedorn, M., Ricker, J., McCarthy, M., Meyers, S.A., Tiersch, T.R., Varga, Z.M. \& Kleinhans, F.W. (2009). Biophysics of Zebrafish (Danio rerio) Sperm. Cryobiology, 58(1): 12-19. 10.1016/j.cryobiol.2008.09.013

Harvey, B. \& Carolsfeld, J. (1993). Preservation of sperm. In: Harvey, B., Carolsfeld, J. (Eds.) Induced breeding in tropical fish culture. Otawa: International Development Research Center, pp. 119-130.

Kuradomi, R.Y., De Souza, T. G., Foresti, F., Schulz, R.W., Bogerd, J., Moreira, R.G., Furlan, L.R., Almeida, E.A., Maschio, L.R. \& Batlouni, S.R. (2016). Effects of re-stripping on the seminal characteristics of pacu (Piaractus mesopotamicus) during the breeding season. General and Comparative Endocrinology, S0016648015001732-.

doi:10.1016/j.ygcen.2015.06.007 
Maria, N.A., Carvalho, A.C.M., Araújo, R.V., Santos, J.P., Carneiro, P.C.F. \& Azevedo, H.C. (2015). Use of cryotubes for the cryopreservation of tambaqui fish semen (Colossoma macropomum). Cryobiology, 70, 109-114.

https://doi.org/10.1016/j.cryobiol.2015.02.004.

Miliorini, A.B., Murgas, L.D.S., Rosa, P.V., Oberlender, G., Pereira, G.J.M. \& Costa, D.V. (2011). A morphological classification proposal for curimba (Prochilodus lineatus) sperm damages after cryopreservation. Aquac. Res., 42, 177187. https://doi.org/10.1111/j.1365-2109.2010.02575.

Muniz, C.C., Alencar, S.S., Castro, A.B., Mello, A.P. \& Ramos, K.C.R. (2014). Seed dispersal by Piaractus mesopotamicus Holmberg, 1887 (Osteichthyes, Characidae) in Taiamã, Northern. Ambiência, 10, 663-

676. https://doi:10.5935/ambiencia.2014.03.01.

Paulino, M.S., Miliorini, A.B., Murgas, L.D.S. \& de Oliveira Felizardo, V. (2018). Desempenho reprodutivo do pacu, piracanjuba e curimba induzidos com extrato de buserelina. Bol. Inst. Pesca, 37,39-45. https://www.pesca.sp.gov.br/boletim/index.php/bip/article/view/37_p1_39-45. (Accessed 27 Jan 2020).

Ribeiro, J.P., Pereira, F.A., Perry, C.T., Pires, D.M., Muelbert, J.R.E., Garcia, J.R.E. \& Varela-Junior, A.S. (2018). Dimethylsulfoxide, methanol and methylglycol in the seminal cryopreservation of Suruvi, Steindachneridion scriptum. Animal Reproduction Science, 200, 7-13. https://doi.org/10.1016/j.anireprosci.2018.09.024.

Shaliutina, A., Hulak, M., Gazo, I., Linhartova, P. \& Linhart, O. (2013). Effect of short-term storage on quality parameters, DNA integrity, and oxidative stress in Russian (Acipenser gueldenstaedtii) and Siberian (Acipenser baerii) sturgeon sperm. Anim. Reprod. Sci. 139, 127-135. https://doi.org/10.1016/j.anireprosci.2013.03.006.

Silva, J.C., Varela Junior, A.S., Caldas, J.S., Da Silva Freitas, C., Botelho, J.G., Colares, E.P. \& Corcini, C. D. (2016). The effects of osmolality on sperm quality in Jenynsia multidentata (Cyprinodontiformes: Anablepidae). Fish. Physiol. Biochem., 42, 93-102. https://doi.org/10.1007/s10695-015-0120-3

Urbinati, E.C., Gonçalves, F.D. \& Takahashi, L.S. (2005). Pacu (Piaractus mesopotamicus). In: Baldisserotto, B.; Gomes, L.C. (Orgs.) Espécies nativas para piscicultura no Brasil. Santa Maria: UFSM, p. 225-255.

Varela Junior, A.S., Corcini, C.D., Streit Jr, D.P., Rizzoto, G., Jardim, R.D., Lucia Jr, T.\& Figueiredo, M.P.C. (2012). Efeito crioprotetor de diferentes concentrações do Dimetilsulfóxido no congelamento de sêmen de Tambaqui Colossoma macropomum. Atlântida, 34, 129-37. https://doi.org/10.5088/atl.2012.34.2.129.

Viveiros, A.T.M., Nascimento, A.F., Leal, M.C., Gonçalves, A.C.S., Orfão, L.H. \& Cosson, J. (2014). Methyl glycol, methanol and DMSO effects on post-thaw motility, velocities, membrane integrity and mitochondrial function of Brycon orbignyanus and Prochilodus lineatus (Characiformes) sperm. Fish. Physiol. Biochem., 41, 193-201. https://doi.org/10.1007/s10695-014-0016-7.

\section{Figures}



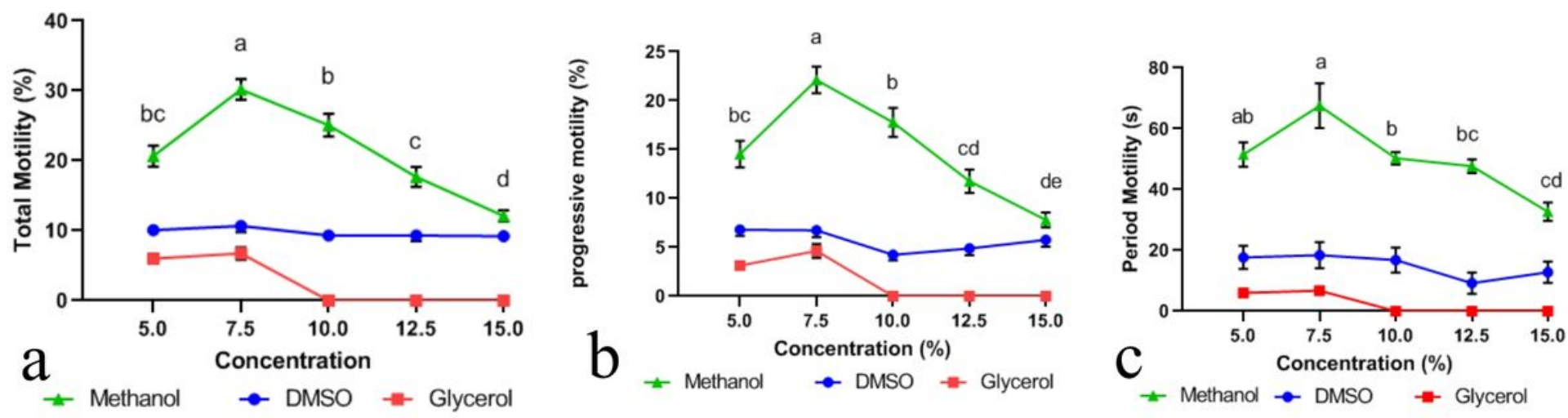

Figure 1

Post-thaw evaluation of $P$. mesopotamicus sperm cells submitted to different treatments. a) total motility; b) Progressive motility and c) Period motility. The data are expressed as mean and standard error of the mean. Abbreviations: dimethylsulfoxide (DMSO). Different letters differ statistically (ANOVA, $\mathrm{P}<0.05$ ). 